\title{
Chess and Mathematics Performance of College Players: An Exploratory Analysis
}

\author{
Gener S. Subia, Jeniffer L. Amaranto, Jeff C. Amaranto, Jacinto Y. Bustamante, Irene C. Damaso \\ Nueva Ecija University of Science and Technology, Cabanatuan City, Philippines \\ Email: subiagener@yahoo.com
}

How to cite this paper: Subia, G.S., Amaranto, J.L., Amaranto, J.C., Bustamante, J.Y. and Damaso, I.C. (2019) Chess and Mathematics Performance of College Players: An Exploratory Analysis. Open Access Library Journal, 6: e5195.

https://doi.org/10.4236/oalib.1105195

Received: January 21, 2019

Accepted: January 28, 2019

Published: January 31, 2019

Copyright ( $\odot 2019$ by author(s) and Open Access Library Inc.

This work is licensed under the Creative Commons Attribution International License (CC BY 4.0).

http://creativecommons.org/licenses/by/4.0/

cc (i) Open Access

\begin{abstract}
The purpose of this study is to explore the performance in Chess and in Mathematics of the college players in Cabanatuan City, Philippines. Specifically, it aimed to determine the respondents' mathematics and chess performances, their playing styles and their beliefs regarding chess players and mathematicians. The descriptive correlational research design was utilized in this study and the data gathered by the researcher were tallied and tabulated using frequency, percentage, mean and Pearson's r. Furthermore, open-ended questions were used to solicit remarks/comments from the respondents regarding the role of chess in enhancing their thinking skills. It was found out that the general weighted average (GWA) in Mathematics of the respondents was above average. Most of them are barangay/school level champions. Males are tactician type of players while females are positional players. A respondent who performed better in higher chess competition also performed better or obtained higher GWA in Mathematics. Furthermore, the respondents believed that a chess player can be a good mathematician especially if they start playing early in life and if chess was a part of the school curriculum since playing chess continuously has helped them in developing and improving their problem solving and critical thinking skills.
\end{abstract}

\section{Subject Areas}

Education, Sociology

\section{Keywords}

Critical Thinking Skills, Mathematics, Problem-Solving, Physical Education, Sport

\section{Introduction}

One goal of 21st-century education is the development of the learners' critical 
thinking and problem-solving since employers in this day and age demand employees with these skills. To cope with this need, teachers should seek better strategies and techniques that will make their learners become critical thinkers and problem solvers.

In the article written by the author in [1], "he mentioned that our educational system is tasked with preparing the next generation to succeed in life and it will substantially fail if it doesn't teach children how to think critically and solve problems". In his post entitled "STEM Education: Why All the Fuss?," he wrote, "Educating students in Science, Technology, Engineering and Mathematics subjects (STEM) (if taught correctly) prepares students for life, regardless of the profession they choose to follow. Those subjects teach students how to think critically and how to solve problems-skills that can be used throughout life to help them get through tough times and take advantage of opportunities whenever they appear."

Seeing that Mathematics is one of the subjects in STEM, learning it is one of the ways that can train the learners to improve their critical and problem-solving skills. Yet, in today's millennial generation where learners are passive receptors of information, Mathematics alone may not motivate them to learn to think critically and solve problems logically. The learners need another technique that can influence them to study Mathematics that is engaging and enjoyable [2]. Since the learners of this generation love to play games, the researchers believe that teaching them to play a sport such as chess game will make them improve their critical thinking and problem-solving skills.

"Chess is a two-player strategy board game played on a chessboard, a checkered game board with 64 squares arranged in an $8 \times 8$ grid. Each player begins with 16 pieces: one king, one queen, two rooks, two knights, two bishops and eight pawns. Each of the six pieces types moves differently, with the most powerful being the queen and the least powerful the pawn [3]". The objective of the chess is to checkmate the opponent's king by placing it under an unavoidable risk of seizure.

There are several studies that show that playing chess improves analytical and problem-solving skills and contributes to mathematics performance such as those that were conducted by [4] [5] [6] [7] and [8]. However, this study was different from those reviewed since aside from investigating the relationship between performance in chess and in mathematics it explored the playing styles of the respondents and describe how chess improves their critical thinking and problem-solving skills. By examining the experiences of these chess players, the results may aid the researchers' ways in improving chess and mathematics performance of future and present varsity players. Likewise, findings of the study may help the researchers in introducing chess game, especially in Physical Education classes, as a tool in developing critical thinking and problem-solving skills of the students which aim to produce better and improved scores for students in problem-solving tasks in mathematics [9]. Thus, this research finds meaning and substance. 


\section{Methodology}

The study utilized a descriptive correlational research design. According to [10], as cited by [11], "Correlational research is employed to test the degree of relationship between two variables".

The respondents of the study who were chosen purposively are 31 college players who came from the four colleges and universities in Cabanatuan City. "Cabanatuan City is a 1st class city in the province of Nueva Ecija, Philippines. According to the 2015 census, it has a population of 302,231 people, making it the most populous city in Nueva Ecija and the 5th populous in Central Luzon" [12].

Secondary materials like the transcript of records from their schools were used to obtain the mathematics grades of the respondents. Likewise, medals, trophies, and certificates were checked and verified to describe the performance of the respondents in chess.

Additionally, an open-ended questionnaire was employed to identify and determine the playing styles of the respondents and the contribution of playing chess in enhancing their critical thinking and problem-solving skills.

The numerical data gathered were tallied and tabulated using frequency, percentage, mean and Pearson's r.

\section{Results and Discussions}

\section{1) Types of Chess Player}

Table 1 revealed that three male respondents were hyper-aggressive although there were no methodical and prophylactic players in both sexes. As stated by the author in [13] "hyper-aggressive players are always looking for an attack or the flashy sacrifice while methodical players don't really prepare for anything and are a mix of everything. They don't have a set of play style and aren't trying to decide the game in the middle. Likewise, Prophylactic players are a rare breed. They are usually a mix of defensive and positional while slightly tactical. They are very strong players and Magnus Carlsen (current World Chess Champion) is a Prophylactic player."

Overall data showed that most of the male respondents were tactical while females were mostly positional. This means that male respondents are strong players and love to dispose of the forces of the opponent when playing chess that was carefully planned to achieve a specific goal. On the other hand, female like to have as many of their pieces in a strong position. They exchange their bad

Table 1. Types of chess player.

\begin{tabular}{cccccccc}
\hline Sex & Hyper-aggressive & Defensive & Tactical & Positional & Methodical & Prophylactic & Total \\
\hline Male & 3 & 6 & 8 & 6 & 0 & 0 & 23 \\
Female & 0 & 0 & 2 & 6 & 0 & 0 & 8 \\
Total & 3 & 6 & 10 & 12 & 0 & 0 & 31 \\
\hline
\end{tabular}


piece over the good piece of their rivals and they give their opponents some trouble in creating any play since they have all the options right in front of them.

This implies that as to playing chess, females' style is quieter and does not try to force action in a game the same way male players do. Females are satisfied with strengthening their own position using their pieces and waiting for the opponent to commit mistakes while males induced very creative traps and tricks in their game.

2) General Weighted Average (GWA) in Mathematics of the Respondents

It can be noted on Table 2 that majority of the respondents' general weighted average (GWA) fall on the grade range of 80 to 84 and 85 to 89 . This means that more than half of the respondents were in the average and above average level in terms of their mathematics performance. It can also be observed on the table that 3 respondents were outstanding (90 - 94) while 2 were excellent (95 - 100) in their GWA in Mathematics. Only 1 respondent failed in Mathematics while 2 obtained a fair performance.

The performance of the respondents when presented using the mean GWA is 85.6, which was verbally described as above average. This means that as to the overall performance in Mathematics of the respondents they are not outstanding or excellent students but they are better compared to ordinary students.

\section{3) Highest. Level of Competition Participated and Won}

It can be observed in Figure 1 that 11 out of 31 respondents have played chess and awarded as champions in barangay/school level.

It can also be seen on the figure that 9 respondents participated and won in the provincial level, 8 respondents played and became champions in the regional level and 3 chess players have been awarded as winners in the National level.

This finding proved that in terms of playing chess, the respondents are competent and are knowledgeable in the said game. This implies that they are appropriate respondents of the study who can properly share and give their opinions and ideas regarding the game and other areas related to it.

4) Correlation between Highest Level of Competition Participated and Won and General Weighted Average in Mathematics

A statistically significant positive relationship has been found between the

Table 2. General weighted average of the respondents in mathematics.

\begin{tabular}{|c|c|c|c|}
\hline GWA in Mathematics & Verbal Description & Frequency & Percent \\
\hline 95 to 100 & Excellent & 2 & 6.5 \\
\hline 90 to 94 & Outstanding & 3 & 9.7 \\
\hline 85 to 89 & Above Average & 14 & 45.2 \\
\hline 80 to 84 & Average & 9 & 29.0 \\
\hline 75 to 79 & Fair & 2 & 6.5 \\
\hline Below 75 & Poor & 1 & 3.2 \\
\hline Total & & 31 & 100.0 \\
\hline
\end{tabular}

Mean GWA of the Respondents $=85.6$. 


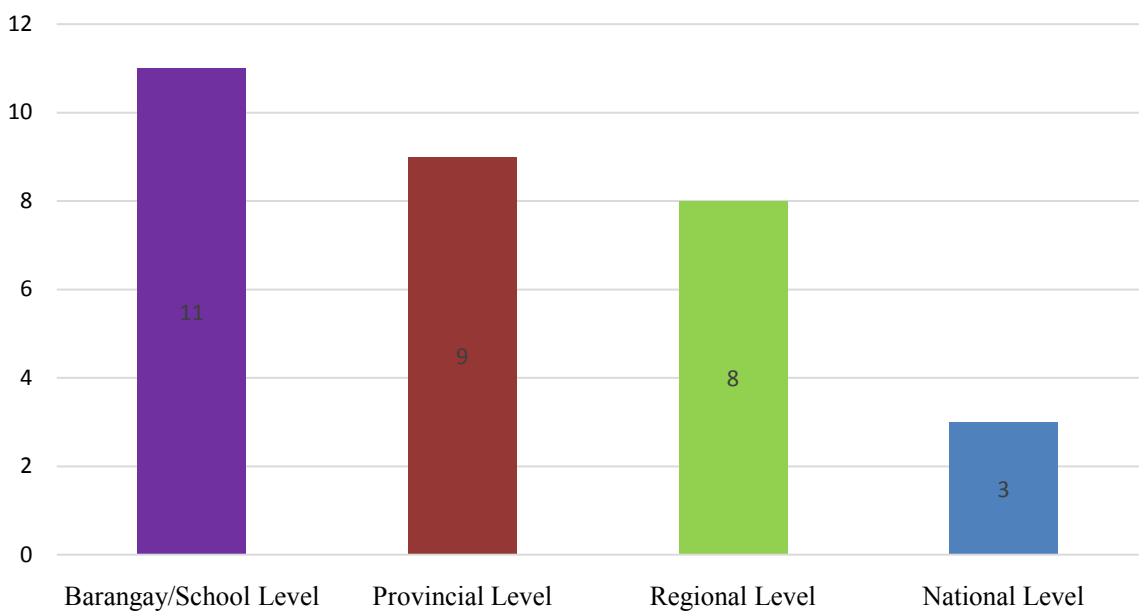

Figure 1. Highest level of competition participated and won by the respondents.

highest level of competition participated and won by the respondents and their GWA in Mathematics $\left(r=0.394^{*}, \mathrm{p}<0.05\right)$. This means that a respondent who has participated and won in the higher level of competition has higher GWA in Mathematics compared to those participating in the lower level competitions. This implies that respondents who performed better in chess also performed better in Mathematics.

The finding is related to the result of the study conducted by authors in [14]. Their data suggests that chess is a vital and potent tool for enhancing the mathematical capability of students.

5) Do you think that Playing Chess improves your Critical Thinking and Problem-Solving Skills?

Below are the narrative answers given by the respondents when they were asked if playing chess develops their critical thinking and problem-solving skills.

Excerpts from Narrative Comments

"Yes, we believe that chess enhances our thinking skills. We believe that good chess players can be good mathematicians if they are properly trained and taught especially because playing chess is more on solving problems using critical thinking just like in studying Mathematics in school. Chess should be included as physical education subject in the Philippine educational system."

"Yes, since playing chess is like solving problems in Mathematics using thorough thinking to find solutions. Chess players always use computations and critical thinking while playing especially those who started playing chess when they were young."

"Yes, because when I start playing chess, I am not fond of solving problems. later on, I began to like and be proficient in problem-solving and I was able to develop my critical thinking skills since to be able to win in chess players computations and analysis should be exact."

"Yes, we experienced it! Chess and mathematics have similarities. Playing chess makes me and my teammates smarter and good problem solvers. It develops our problem solving, critical thinking and computational skills". 
The narration showed that the respondents believed that their critical thinking and problem-solving skills were developed in the respondents' years of playing chess. "Mathematicians who play chess usually admit that chess is a part of Mathematics and it is the most mathematical of all strategic games. Mathematics is considered the queen of the sciences while Chess is the queen of all board games. Both share an abstract way of reasoning in solving problems. Mathematics, like chess, is one of the things where constant practice, constant thinking, and imagining, and studying are necessary to achieve mastery of the subject" [15]. Therefore, a good chess player can be a good mathematician if properly trained and educated. The finding of the recent study is supported by the post of [15] regarding famous chess players who are also mathematicians namely: Adolf Anderssen (1818-1879); Emanuel Lasker (1868-1941); Albert Einstein (1879-1955); Max Euwe (1901-1981); Paul Keres (1916-1975); and Karsten Mueller (1970-present).

\section{Conclusions and Recommendations}

The study found out that the respondents were mostly males. Their general weighted average (GWA) in Mathematics was above average. Most of them are barangay/school level champions. Males are tactician type of players while females are positional players. A respondent who performed better in higher chess competition also performed better or obtained higher GWA in Mathematics. They believed that a good chess player can be a good mathematician if they start playing early in life and if chess was a part of the school curriculum since playing chess continuously has helped them in developing and enhancing their problem solving and critical thinking skills.

Based on the results of the study and the findings of the different studies reviewed, it is recommended that the administrators of the Department of Education and Commission on Higher Education of the Philippines may consider the inclusion of Chess in the current $\mathrm{K}$ to 12 curricula to help the teachers in developing the students' critical thinking and problem-solving skills. School administrators may contemplate on hiring teachers who are chess professionals and are proficient in Mathematics and other related disciplines. Likewise, teachers and professors may consider injecting games in their teaching-learning process which can develop critical and problem-solving skills of their students. Moreover, further research may be conducted examining other factors related to the importance of playing chess and the school abilities of students.

\section{Conflicts of Interest}

The authors declare no conflicts of interest regarding the publication of this paper.

\section{References}

[1] Deangalis, S. (2014) Why STEM? Success Starts with Critical Thinking, Problem-Solving Skills.

https://www.wired.com/insights/2014/06/stem-success-starts-critical-thinking-prob lem-solving-skills/ 
[2] Subia, G.S. (2018) Comprehensible Technique in Solving Consecutive Number Problems in Algebra. Journal of Applied Mathematics and Physics, 6, 447-457. https://doi.org/10.4236/jamp.2018.63041

[3] Chisholm, H. (1911) "Chess". In: Encyclopædia Britannica, 6. 11th Edition, Cambridge University Press, Cambridge.

https://en.wikipedia.org/wiki/Chess\#cite_note-EB1911-1

[4] Boruch, R. (2011) Does Playing Chess Improve Math Learning? Promising (and Inexpensive) Results from Italy. Unpublished Manuscript.

[5] Aciego R, García L, Betancort, M. (2012) The Benefits of Chess for the Intellectual and Social-Emotional Enrichment in Schoolchildren. The Spanish Journal of Psychology, 15, 551-559. https://doi.org/10.5209/rev_SJOP.2012.v15.n2.38866

[6] Burgoyne, A.P., Sala, G., Gobet, F., Macnamara, B.N., Campitelli, G. and Hambrick, D.Z. (2016) The Relationship between Cognitive Ability and Chess Skill: A Comprehensive Meta-Analysis. Intelligence, 59, 72-83.

https://doi.org/10.1016/j.intell.2016.08.002

[7] Sala, G. and Gobet, F. (2016) Do the Benefits of Chess Instruction Transfer to Academic and Cognitive Skills. Educational Research Review, 18, 46-57. https://doi.org/10.1016/j.edurev.2016.02.002

[8] Sala, G., Foley, P.J. and Gobet, F. (2017) The Effect of Chess Instruction on Pupil's Cognitive and Academic Skills: State of the Art and Theoretical Challenges. Frontiers in Psychology, 8, 238. https://doi.org/10.3389/fpsyg.2017.00238

[9] Del Rosario, J., Subia, G. and Lopez, C. (2018) Preparing Junior High School Students in Science, Technology, Engineering and Mathematics (STEM) Track Using Journal Writing in Mathematics. International Journal of Advanced Engineering, Management, and Science, 4, 749-752. https://doi.org/10.22161/ijaems.4.11.1

[10] Patten, M.L. (2002) Understanding Research Methods. Pyrczak Publishing, U.S.A.

[11] Subia, G., Salangsang, L. and Medrano, H. (2018) Attitude and Performance in Mathematics of Bachelor of Elementary Education Students: A Correlational Analysis. American Scientific Research Journal for Engineering, Technology, and Sciences (ASRJETS), 39, 206-213.

[12] Census of Population (2015) Total population by Province, City, Municipality, and Barangay. PSA Region III (Central Luzon).

[13] Roden, J. (2012) Types of Chess Players. Dallas, U.S.A. https://www.chess.com/forum/view/chess-players/types-of-chess-players

[14] Rosholm, M., Mikkelsen, M. and Gumede, K. (2017) Your Move: The Effect of Chess on Mathematics Test Scores. PloS (Public Library of Science) One, 12, e0177257. https://doi.org/10.1371/journal.pone.0177257

[15] Bill (2015) Mathematicians Who Play Chess. http://www.chessmaniac.com/mathematicians-who-play-chess/ 